\title{
Larynx, hypopharynx and mandible injury due to external penetrating neck injury
}

\author{
Eksternal penetran boyun yaralanmasına bağlı gelişen larinks, \\ hipofarinks ve mandibula yaralanması
}

Gül ÖZBİLEN ACAR, Muhammet TEKİN, Osman H. ÇAM, Emre KAYTANCI

Esophageal and laryngeal injuries due to ballistic injuries are seldom encountered. Ballistic external neck traumas generally result in death. Incidence of external penetrant neck injuries may vary between 1/5000-137000 patients among emergency service referrals. Vascular injuries, esophagushypopharynx perforations, laryngotracheal injuries, bony fractures, and segmentations may be encountered in external neck traumas. Here we report a 27 -year-old male patient who was referred to our emergency department and presented with hyoid bone fracture, multiple mandibular fractures, and hypopharynx perforation due to a ballistic external neck injury.

Key Words: Ballistic injury; external neck trauma; hypopharynx perforation; hyoid fracture; mandible fracture.
Blastik travmalara bağlı özöfageal ve laringeal yaralanmalar nadir görülürler. Blastik travmalara bağlı gelişen dış boyun travmaları genellikle ölümle sonuçlanır. Penetran dış boyun travmalarının acil servise başvuran hastalar arasındaki insidansı 1/5000-137000 arasında değişmektedir. Dış boyun travmalarında vasküler yaralanmalar, özofagus-hipofarenks perforasyonları, laringotrakeal yaralanmalar, kemik yapılarda kırık ve parçalanmalar görülebilir. $\mathrm{Bu}$ yazıda, eksternal blastik boyun travmasına bağlı olarak acil servise başvuran hiyoid kırığı, multipl mandibula kırığı ve hipofarenks perforasyonu saptanan 27 yaşındaki erkek hasta sunuldu.

Anahtar Sözcükler: Blastik travma; eksternal boyun travması; hipofarenks perforasyonu; hiyoid kırığ1; mandibula kırığı.
Pharyngoesophageal perforations due to blunt head and neck traumas are well described in the literature while laryngotracheal and pharyngoesophageal injuries due to ballistic traumas remain unclear due to the rarity of these cases. Traumas to the head and neck regions have vital importance because of major vascular structures. ${ }^{[1]}$ Deaths due to traumas of the head and neck regions are generally related with vascular injuries. Neck injuries are classified in three zones. ${ }^{[2]}$

In management of traumatic head and neck injuries, it is still controversial to make immediate surgical exploration or to make serial physical examinations ${ }^{[3]}$ (including angiography, with endoscopic examinations and selective surgical exploration).

In this paper we report the approach and management of a patient admitted to the emergency depart- ment with ballistic neck trauma resulting in hyoid, hypopharynx, and mandibular injuries without major vascular injury.

\section{CASE REPORT}

A 27-year-old male was referred to our emergency department because of ballistic neck trauma in July 2009. In the first examination of the patient, soft tissue injury in the right cheek and mouth floor was observed. Edema and hematoma in the uvula and soft palate were also present. In palpation, edema in the left and right side of the mandible, malocclusion of the jaw, and stepping sign of the bony structure were discovered.

The patient had difficulty swallowing and had blood mixed with saliva inside the mouth due to the fracture of the mandible. There were a total of three 
bullet entry points: one in the left side of the neck on mandibular corpus, near the midline about $1 \mathrm{~cm}$ with irregular edges; a second about $1 \mathrm{~cm}$ in the left inferior lobule of auricle with irregular edges; and a third in the left side about $2 \mathrm{~cm}$ inferior mandibular corpus with irregular edges. In the left neck, air bubbles drew attention from one of the defects which was approximately $2 \mathrm{~cm}$ inferior from mandibular corpus.

In the neck on the right side of the mandibular corpus, there were two $1 \mathrm{~cm}$ length bullet exits: the first in the midline and the second more anteriorly. Due to the entrance of the bullet in the left shoulder, there were two wounds about $1 \mathrm{~cm}$ in diameter with irregular edges, surrounded by ecchymosis, and one irregular wound on the right deltoideopectoral side 1 $\mathrm{cm}$ in diameter with ecchymosis around. All wounds had minimal hemorrhages.

The patient had mild respiratory distress, and had moderate subcutaneous emphysema. However, due to lack of cyanosis, major airway pathology was not thought. after airway application with intravenous access, standard cranial and neck computed tomography (CT) and a 3D cranium CT imaging were performed.

In the neck CT, hyoid bone corpus fracture was observed using an aerial image between soft tissue at the level of tongue base and neck. Additionally, foreign body artifact was seen inside the mouth. Multiple fracture lines including the right and left side of the mandibular corpus were seen. Doppler ultrasonography of bilateral carotid arteries and flow rates were within normal limits. The patient's carotid sheath remained intact, so angiography was not performed.

The patient was operated on by a team consisting of ear, nose, and throat (ENT), general, plastic, and cardiovascular surgeons. The patient was intubated nasotracheally under general anesthesia. Flexible endoscopy was performed by general surgeons. Esophagus was evaluated as normal. Then, direct laryngoscopy was performed by the ENT team. Edema and hyperemia were seen in the vocal cords and the band ventricles. Suspicious mucosal tears were observed in the mucosa of the left hypopharynx. Then, the neck was explored. Apron flap was elevated. The carotid sheath was investigated by vascular surgery consultant on the left side of the neck for possibility of a major vessel dissection. The carotid artery and the internal jugular vein were both intact.

On the left side of the neck approximately $2 \mathrm{~cm}$ inferior to mandibular corpus, the tract caused by a skin defect was followed and was seen entering the hypopharynx. The left half portion of the hyoid bone corpus was fractured and the left side of the esophagus was perforated by a bullet. The right side of the hyoid bone was intact. The damaged portion of the hyoid was excised. The left side of the esophageal injury was repaired. There was also damage on the right side of the esophagus at the same level of the hypopharynx. Esophageal injury was repaired on the right side. The muscles and subcutaneous tissues on right and left sides were transposed and sutured to the hypopharynx defect and reconstruction was performed.

There was a $1 \mathrm{~cm}$ laceration in the soft palate on the left side. There was a defect approximately 1.5 to $2 \mathrm{~cm}$ in size in the mouth floor on the right side. All lacerations in the mouth were sutured. Two hemovac drains were inserted into the surgical field and tracheotomy was performed between second and third tracheal rings. Neck was closed with subcutaneous and skin sutures.

Oropharynx was examined with the help of mouth gag opener. On the right side at the level of second and third molar teeth, there was a mandibular defect with a 1.5 to $2 \mathrm{~cm}$ laceration of the buccal mucosa adjacent. One bullet stuck in the lacerations among the soft tissues was removed. Other entry and exit holes in the neck were sutured, primarily after desepithelization. Upper and lower jaws were stabilized and fixated with the help of arch bars by the plastic surgeon.

A nasogastric tube was applied. The patient was transferred to the Intensive Care Unit with tracheotomy. On postoperative seventh day, the patient underwent a control Doppler ultrasonography. The vascular flow rates were within the normal limits. After 10 days postoperatively, all the sutures were removed and the patient was decannulated and fed orally. The patient was discharged to be followed by plastic surgery outpatient clinic.

\section{DISCUSSION}

As always, the first step in penetrating neck trauma patients is to ensure the safety of the airway. After making sure that there is no interruption or obstruction in the airway, vascular injury and hemodynamics must be checked. Three quarters of patients with laryngotracheal injury need airway intervention. ${ }^{[4]}$ Intubation or emergent cricothyroidotomy must be performed in cases of airway interruption. In our patient, the existence of mild respiratory distress and subcutaneous emphysema as well as possible laryngotracheal or hypopharyngeal injury was considered.

Vascular injury is one of the most important markers in determining mortality and morbidity. Although there was no evidence of vascular injury in carotid Doppler ultrasonography of our patient, carotid sheath was explored and followed during the vascular trace for exclusion of the blast effect of the bullet resulting a possible aneurysm, pseudoaneurysm, or dissection. In ballistic, injuries occult bullet embolism, either arte- 
rial or venous, is also well described in the literature. ${ }^{[5]}$ Dyspnea, hemoptysis, and chest pain are the major symptoms of venous bullet embolism while claudication, peripheral ischemia, and thrombophlebitis are the symptoms of arterial embolism. Our patient had only mild dyspnea, so bullet embolism was not mainly considered.

Indications that immediate exploration for any penetrating neck injuries, regardless of zone, is necessary include active external hemorrhage, hemoptysis, stridor, and pulsatile or expanding hematoma. ${ }^{[6]}$ Our patient had none of the symptoms above. For asymptomatic patients, there are some studies envisaging vascular exploration for selective cases in neck injuries. ${ }^{[7]}$ The hypopharynx and esophagus injury may occur as a result of direct damage, or it may occur by blast damage as well. In our patient, the skin defect was observed and the tract was followed up to the hypopharynx perforation.

Currently there is no consensus regarding the conservative treatment of penetrating neck trauma patients. After CT angiography, endoscopy, and laryngoscopy, follow up is an option, as there are some authors who suggest aggressive surgical exploration especially in case of suspicious cervical esophageal injury. ${ }^{[8,9]}$ Our patient had mild dyspnea, subcutaneous emphysema and mild oropharyngeal hemorrhage symptoms accompanied by edema and hyperemia in the vocal cords and the band ventricles. Possible laryngotracheal injury with/without vascular damage was prediagnosed and selective neck exploration was performed.
In conclusion, ballistic neck traumas are crisis management cases and multidisciplinary evaluation is needed during approach. Selective neck exploration is still controversial. We need more studies with huge patient follow up to clarify this discussion.

Conflict-of-interest issues regarding the authorship or article: None declared.

\section{REFERENCES}

1. Preston T, Fedok FG. Blunt and penetrating trauma to the larynx and upper airway. Operative Techniques in Otolaryngology 2007;18:140-3.

2. Monson DO, Saletta JD, Freeark RJ. Carotid vertebral trauma. J Trauma 1969;9:987-99.

3. Osborn TM, Bell RB, Qaisi W, Long WB. Computed tomographic angiography as an aid to clinical decision making in the selective management of penetrating injuries to the neck: a reduction in the need for operative exploration. J Trauma 2008;64:1466-71

4. Young O, Watters K, Sheahan P, Hughes J. Penetrating air gun wound in the neck. Auris Nasus Larynx 2008;35:426-8.

5. Greaves N. Gunshot bullet embolus with pellet migration from the left brachiocephalic vein to the right ventricle: a case report. Scand J Trauma Resusc Emerg Med 2010;18:36.

6. Sekharan J, Dennis JW, Veldenz HC, Miranda F, Frykberg ER. Continued experience with physical examination alone for evaluation and management of penetrating zone 2 neck injuries: results of 145 cases. J Vasc Surg 2000;32:483-9.

7. Klyachkin ML, Rohmiller M, Charash WE, Sloan DA, Kearney PA. Penetrating injuries of the neck: selective management evolving. Am Surg 1997;63:189-94.

8. Woo K, Magner DP, Wilson MT, Margulies DR. CT angiography in penetrating neck trauma reduces the need for operative neck exploration. Am Surg 2005;71:754-8.

9. Henderson E, Echavé V, Lalancette M, Langlois G. Esophageal perforation in closed neck trauma. Can J Surg 2007;50:E5-6. 